\title{
Correlation between Global Emissions of $\alpha$-hexachlorocyclohexane and Its Concentrations in the Arctic Air
}

\author{
Y. F. $\mathrm{Li}^{*}$ and T. F. Bidleman \\ Meteorological Service of Canada, Environment Canada, 4905 Dufferin Street, Downsview, Ontario M3H 5T4, Canada
}

\begin{abstract}
The mean air concentrations of $\alpha$-hexachlorocyclohexane $(\mathrm{HCH})$ in the Arctic responded quickly to the change of global $\alpha-\mathrm{HCH}$ emissions from 1979 to the early 1990, and the air concentrations in the Arctic and global emissions of $\alpha-\mathrm{HCH}$ are strongly correlated with correlation coefficient $\mathrm{r}^{2}=0.90$. The quick response and the strong correlation indicate that atmospheric long-range transport was the dominant pathway for $\alpha-\mathrm{HCH}$ to enter arctic air before early $1990 \mathrm{~s}$. An equation is derived from the least-square equation to calculate the annual concentrations of $\alpha-\mathrm{HCH}$ in arctic air from global annual $\alpha-\mathrm{HCH}$ emissions between 1945 and 1990, and the results indicate that a reasonable estimate of historical air concentration of $\alpha-\mathrm{HCH}$ in the Arctic can be inferred from the global emission data.
\end{abstract}

Keywords: Arctic, concentration, correlation, emission, $\mathrm{HCH}$, organochlorine pesticides, pathway, pesticides

\section{Introduction}

Technical hexachlorocyclohexane $(\mathrm{HCH})$ and lindane are two formulations of organochlorine pesticide $\mathrm{HCH}$, and have been used throughout the world since 1940s. A total of eight $\mathrm{HCH}$ isomers have been identified in technical $\mathrm{HCH}$. However, only the $\alpha-, \beta-, \gamma-, \delta$ - and $\varepsilon$-isomers are stable and these are the ones commonly identified in technical $\mathrm{HCH}$. Generally, technical $\mathrm{HCH}$ contains the isomers in the following percentages (Kutz et al., 1991): $\alpha$ : $60-70 \%, \beta: 5-12 \%, \gamma: 10-12 \%, \delta: 6-10 \%$, and $\varepsilon: 3-4 \%$. Lindane contains more than $90 \%$ of $\gamma-\mathrm{HCH}$ (IRPTC, 1983). Only $\gamma$-HCH displays significant insecticidal properties.

$\alpha-\mathrm{HCH}$ is a prominent contaminant found in the Arctic, and is one of the most studied chemicals in arctic environmental research. The chemical budget to the surface Arctic Ocean layer has been reconstructed for total $\mathrm{HCH}$ $(\alpha-\mathrm{HCH}$ plus $\gamma-\mathrm{HCH})$ in the 1980s (Barrie et al., 1992), for $\alpha-\mathrm{HCH}$ and $\gamma-\mathrm{HCH}$ in the 1990s (Macdonald et al., 2000). These estimates were made for the entire Arctic Ocean. Historical budgets (1980-95) were estimated for $\alpha-\mathrm{HCH}$ and $\beta-\mathrm{HCH}$ in the North American Arctic Ocean (NAAO) ( $\mathrm{Li}$ et al., 2002). Constructing a historical $\mathrm{HCH}$ budget is important since it can help to develop an understanding of the processes controlling the input, output and fate of this chemical as well as to identify knowledge gaps critical to prediction of future trends. To achieve this, however, is very difficult, due to the lack of data. The

\footnotetext{
* Corresponding author: yi-fan.li@ec.gc.ca
}

collection of arctic data was started at the end of the 1970s. One of the most important records is the historical concentration of $\mathrm{HCHs}$ in the arctic atmosphere.

The relationship between the global technical $\mathrm{HCH}$ use trends and the concentration of $\alpha-\mathrm{HCH}$ in the arctic atmosphere has been studied (Li et al., 1998). Two significant drops in global technical $\mathrm{HCH}$ usage were identified, one in 1983 when China banned the use of technical $\mathrm{HCH}$, and another one in 1990 when both India and Soviet Union banned the use of technical $\mathrm{HCH}$ in agriculture. Significant drops in $\alpha-\mathrm{HCH}$ concentration in arctic air were observed between 1982 and 1983, and again between 1990 and 1992 (Bidleman et al., 1995; Li et al., 1998). These two sharp decreases of air concentration of $\alpha-\mathrm{HCH}$ in the Arctic seem to be the responses to the change of global technical HCH usage (Li et al., 1998).

Historical technical $\mathrm{HCH}$ usage and contamination consequences in the environment by this chemical have been reviewed by Li (1999a), and the global annual usage data have been gridded with a $1^{\circ} \times 1^{\circ}$ longitude/latitude resolution by using global cropland as a surrogate $(\mathrm{Li}$, 1999b). Emission factors of $\alpha-\mathrm{HCH}$ for spray and tilling events were distributed on a $1^{\circ} \times 1^{\circ}$ longitude and latitude grid system. By combining emission factors and usage data, global gridded emission inventories have been created (Li et al., 2000). Based on the results of these works, this paper is to present the correlation between global emissions of $\alpha-\mathrm{HCH}$ and its concentrations in arctic air, to derive an equation to calculate the annual concentrations of $\alpha-\mathrm{HCH}$ in arctic air from its annual global emissions, and to discuss other possible sources of $\alpha-\mathrm{HCH}$ in arctic air. 


\section{Correlation between Global Emissions of $\alpha-\mathrm{HCH}$ and its Concentrations in Arctic Air}

Around 6 million t of $\alpha-\mathrm{HCH}$ were used, and 4.3 million $\mathrm{t}$ were emitted to the atmospheric worldwide between 1945 and 2000 (Li, 1999b; Li et al., 2000). Annual global emissions of $\alpha-\mathrm{HCH}$ between 1945 and 2000 are presented in Figure 1.

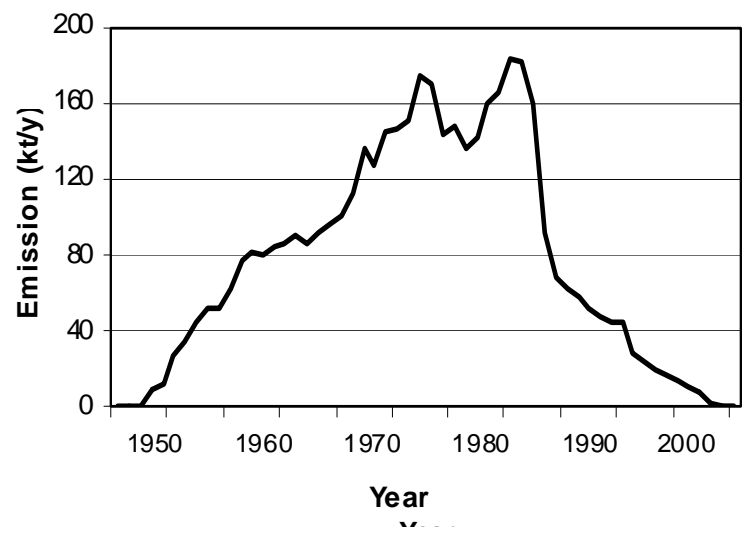

Figure 1. Annual global emissions of $\alpha-\mathrm{HCH}$ between 1945 and 2000.

Figure 2 shows the long-term trends of global emissions of $\alpha-\mathrm{HCH}$ and its mean air concentrations in the arctic regions from 1979 to 1998 . The trends shown here are similar to those shown in Li et al. (1998), which compared air concentrations with global technical $\mathrm{HCH}$ usage. Comparison of Figure 2 to Figure 1 in $\mathrm{Li}$ et al. (1998) shows a more correlated relationship of air concentrations with $\alpha-\mathrm{HCH}$ emissions than technical $\mathrm{HCH}$ usage.

A plot of mean air concentrations of $\alpha-\mathrm{HCH}$ in the Arctic versus global $\alpha-\mathrm{HCH}$ emissions is shown in Figure 3. It indicates that global emissions of $\alpha-\mathrm{HCH}$ and its mean air concentrations in arctic regions from 1979 to early 1990 s are strongly correlated with correlation coefficient $r^{2}=0.90$, and the least-squares line is

$C=4.31 E+83.4$

where $C$ is the air concentration $\left(\mathrm{pg} \mathrm{m}^{-3}\right)$, and $\mathrm{E}$ the emission $\left(\mathrm{kt} \mathrm{y}^{-1}\right)$. It is interesting to see that the diamonds in the figure scatter into three groups, the first one in the top of the figure, the second in the middle, and the third at the bottom. There are two gaps between these three groups, representing the two drops of both global emissions and air concentrations of $\alpha-\mathrm{HCH}$, one happened after 1983 and another after 1990.

\section{Pathways of $\alpha-\mathrm{HCH}$ to the Arctic}

The quick response of $\alpha-\mathrm{HCH}$ concentration in the Arctic air to the change of global $\alpha-\mathrm{HCH}$ emission is the strongest evidence that atmospheric long-range transport provides rapid dispersion of $\alpha-\mathrm{HCH}$ from its release point (mainly Asian) into the Arctic. The second piece of evidence is the relatively high concentrations of $\alpha-\mathrm{HCH}$ in northern surface waters of the Pacific and in the Arctic Ocean (cold condensation), illustrates the importance of atmospheric transport especially in the early "ocean loading" stage (Li et al., 2002).

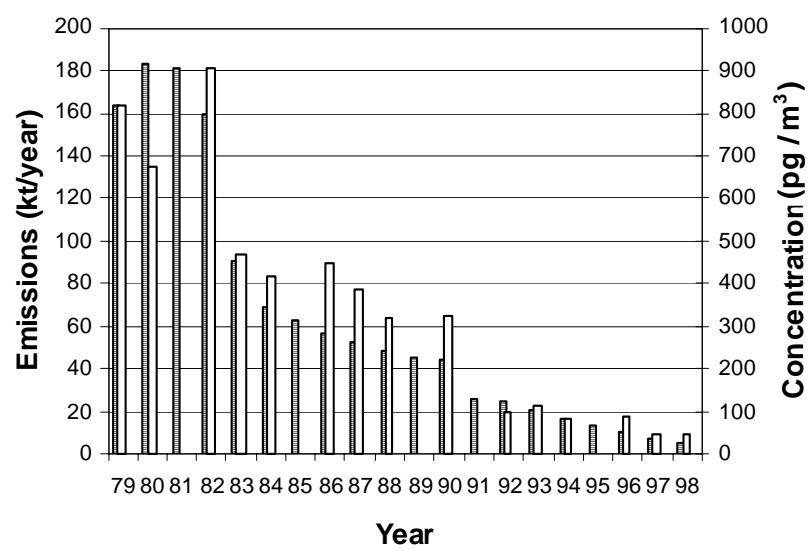

Note: Air concentration data of $\alpha-\mathrm{HCH}$ in the Arctic have been measured at different stations by several research groups (Bidleman et al. 1995; Falconer et al., 1995; Halsall et al., 1998; Hargrave et al., 1988; Harner et al., 1999; Hinckley et al., 1991; Hung et al., 2002; Iwata et al., 1993; Jantunen and Bidleman, 1995, 1996; Oehme and Ottar, 1984; Oehme, 1991; Oehme et al., 1995, 1996; Pacyna and Oehme, 1988; Patton et al., 1989, 1991; Tanabe and Tatsukawa, 1980).

Figure 2. Global emissions of $\alpha-\mathrm{HCH}$ (the left bars with shadow) and mean concentrations of $\alpha-\mathrm{HCH}$ in the Arctic air (the right empty bars) from 1979 to 1998.

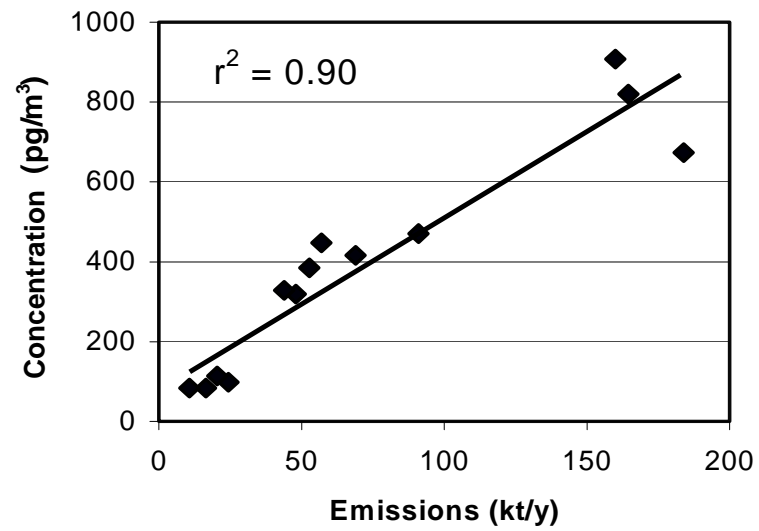

Figure 3. Correlation between global emissions of $\alpha-\mathrm{HCH}$ and its concentrations in arctic air with $r^{2}=0.90$. The least-squares line is given by Equation (1).

Table 1 gives the percentages of input of $\alpha-\mathrm{HCH}$ to the North American Arctic Ocean (NAAO) (Li et al., 2002). The table shows that in 1980 flow through the Bering Strait and atmospheric deposition were about equally effective in delivering $\alpha-\mathrm{HCH}$ to the NAAO, which ac- 
counts for about one quarter of the Arctic Ocean surface area. Atmospheric deposition to the entire Arctic Ocean in the mid-1990s was estimated to be approximately half as great as loadings by ocean currents (Macdonald et al., 2000) and was probably more significant in the past when air concentrations were higher.

Table 1. Estimated Input of $\alpha-\mathrm{HCH}$ to the North American Arctic Ocean, (\%) (Li et al., 2002)

\begin{tabular}{llll}
\hline Year & $\begin{array}{l}\text { Bering } \\
\text { Strait inflow }\end{array}$ & $\begin{array}{l}\text { Direct } \\
\text { atmospheric } \\
\text { deposition }\end{array}$ & Snowmelt \\
\hline 1980 & 51.4 & 42.7 & 5.9 \\
1985 & 62.4 & 33.3 & 4.3 \\
1995 & 90 & $-2.5^{2}$ & 12.5 \\
\hline
\end{tabular}

${ }^{1}$ Total inputs during 1980, 1985 and 1995 by atmospheric processes and Bering Strait flow were 124, 92.5 and $54.3 \mathrm{t} \mathrm{y}^{-1}$, respectively.

${ }^{2}$ The negative value indicates the air-sea gas exchange flux of $\alpha-\mathrm{HCH}$ is volatilization.

The $\alpha-\mathrm{HCH}$ may enter the arctic atmosphere through two major pathways. Atmospheric long-range transport can bring $\alpha-\mathrm{HCH}$ directly from source region, and volatilization can transfer $\alpha-\mathrm{HCH}$ from the Arctic Ocean to arctic air. Before the early $1990 \mathrm{~s}$, most of the $\alpha-\mathrm{HCH}$ in arctic air was due to atmospheric long-range transport since the net air-sea exchange flux was deposition. The quick response and strong correlation of $\alpha-\mathrm{HCH}$ air concentrations in the Arctic to the global $\alpha-\mathrm{HCH}$ emissions indicate that atmospheric long-range transport was the main pathway for $\alpha-\mathrm{HCH}$ to enter-arctic air before the early 1990s.

However, this situation has changed since the early 1990s. The measured fugacity ratios $(\Gamma$, eq 2$)$ of $\alpha-\mathrm{HCH}$ in the NAAO and Bering Sea were $>1$ around 1993-1994 (Jantunen and Bidleman, 1995; 1996), which indicates that the net flux of $\alpha-\mathrm{HCH}$ was from sea to air. This change was supported by enantiomeric profiles in air, which showed that nonracemic $\alpha-\mathrm{HCH}$ from unfrozen areas of the ocean was undergoing volatilization (Jantunen and Bidleman, 1996). The situation for 1993-94 was recently reassessed using a new and somewhat lower value for the $\alpha-\mathrm{HCH}$ Henry's law constant (see below), with the result that $\alpha-\mathrm{HCH}$ was significantly oversaturated $(\Gamma>1)$ in the Bering and Beaufort Seas and near air-water equilibrium in the Chukchi Sea and the Northern Canada Basin (Sahsuvar et al., 2002). Thus, after the early 1990s sources of $\alpha-\mathrm{HCH}$ in arctic air have been due to both atmospheric transport and volatilization from arctic waters.

The driving force for the reversal of the net flux of $\alpha-\mathrm{HCH}$ in the beginning of $1990 \mathrm{~s}$ is the decrease in atmospheric concentrations of $\alpha-\mathrm{HCH}$, while concentrations of $\alpha-\mathrm{HCH}$ in water have declined at a much slower rate (Jantunen and Bidleman, 1995). In fact, it was the sudden decrease of global $\alpha-\mathrm{HCH}$ emissions in 1990 that caused the decrease of $\alpha-\mathrm{HCH}$ concentrations in the arctic atmosphere (see Figure 2), which reversed the net flux direction of $\alpha-\mathrm{HCH}$ from air-to-sea to sea-to-air.

The water-air fugacity ratio is given by (Jantunen and Bidleman, 1995)

$\Gamma=f_{w} / f_{a}=\left(C_{w} / C_{a}\right)(H / R T)$

where $f_{w}$ and $f_{a}$ are the fugacities in water and air (in pascals), $C_{w}$ and $C_{a}$ are the concentrations of dissolved and gaseous compounds in water and air $\left(\mathrm{ng} \mathrm{m}^{-3}\right), R$ is the gas constant $\left(8.314 \mathrm{~Pa} \mathrm{~m}^{3} \mathrm{~mol}^{-1} \mathrm{~K}^{-1}\right), T$ is the air temperature $(\mathrm{K})$, and $H$ the Henry's law constant (air-water partition coefficient, $\mathrm{Pa} \mathrm{m} \mathrm{mol}^{-1}$ ) at the temperature $T$ of the surface seawater. Fugacity ratios of $<1$ and $>1$ indicate net deposition and volatilization, while a ratio $=1$ implies air-water equilibrium according to Henry's law (Jantunen and Bidleman, 1995):

$\left(C_{a} / C_{w}\right)_{e q}=H / R T$

The most recent measurements of the $\alpha-\mathrm{HCH}$ Henry's law constant in freshwater as a function of temperature give the relationship (Sahsuvar et al., 2002):

$\log H_{\alpha}=10.13( \pm 0.29)-3098( \pm 84) / T$

The Henry's law constant at $0{ }^{\circ} \mathrm{C}$ from Equation (4) agrees well with that measured by Jantunen and Bidleman (2000) and is about 1.7 times lower than the value determined by Kucklick et al. (1991), on which previous estimates of air-water gas exchange in the Arctic Ocean were based (Jantunen and Bidleman, 1995, 1996). Using Equation (4) and assuming a $21 \%$ salting-out effect in seawater of 35 psu salinity (Sahsuvar et al., 2002), the Henry's law constant for $\alpha-\mathrm{HCH}$ in seawater at $0{ }^{\circ} \mathrm{C}$ is $0.074 \mathrm{~Pa} \mathrm{~m}^{3} \mathrm{~mol}^{-1}$.

Before early 1990s, even though there was a large amount of $\alpha-\mathrm{HCH}$ entering the NAAO from the Pacific Ocean via the Bering Strait, the portion of $\alpha-\mathrm{HCH}$ entering the arctic atmosphere via long-range transport from source regions was still playing a prominent role (Table 1) and the net flux of $\alpha-\mathrm{HCH}$ was deposition $(\Gamma<1)$. After early $1990 \mathrm{~s}$, the amount of $\alpha-\mathrm{HCH}$ entering the arctic atmosphere via long-range transport has been significantly reduced to a point such that $\Gamma \geq 1$, and the $\alpha-\mathrm{HCH}$ in surface water has been at equilibrium or oversaturated with respect to atmospheric concentrations.

Concentrations of $\alpha-\mathrm{HCH}$ in the- surface water of the Bering and Chukchi seas were measured in the summer of 1993 and two additional stations in the Chukchi were sampled in 1994 (Jantunen and Bidleman, 1996). Combined data from two years measurements show that, in the upper $40 \mathrm{~m}$ of seawater over the entire Bering-Chukchi region, the average concentration was $2020 \pm$ 
$380 \mathrm{ng} \mathrm{m}^{-3}$ (Jantunen and Bidleman, 1996). This is 2 to 5 times higher than the surface water concentrations in the Barents Sea and eastern Arctic Ocean (Harner et al., 1999) and about 0.5-0.8 times the concentrations in the Beaufort Sea and Northern Canada Basin (Sahsuvar et al., 2002). Only the unfrozen portions of the Arctic Ocean are likely to participate effectively in gas exchange with the atmosphere. This area varies seasonally, but probably includes the Bering-Chukchi seas, Canadian Archipelago and regional seas and lower portions of the eastern Arctic Ocean. The Beaufort Sea and high arctic regions are mainly ice covered.

Applying a Henry's law constant of $0.074 \mathrm{~Pa} \mathrm{~m}^{3}$ $\mathrm{mol}^{-1}$ at $0{ }^{\circ} \mathrm{C}$ gives an air concentration in equilibrium with surface water of $66 \mathrm{pg} \mathrm{m}^{-3}$ in the Bering-Chukchi seas. A lower equilibrium value of $33 \mathrm{pg} \mathrm{m}^{-3}$ is obtained by equilibration with air over the eastern Arctic Ocean, where the concentration of $\alpha-\mathrm{HCH}$ in surface water is about $1000 \mathrm{ng} \mathrm{m}^{-3}$. (Harner et al., 1999). Measured concentrations in arctic air varied from about $60-110 \mathrm{pg}$ $\mathrm{m}^{-3}$ in 1992-94 depending on the study (Figure 2: note that there are many relevent publications in this time period: Halsall et al., 1998; Jantunen and Bidleman, 1995, 1996; Oehme et al., 1995, 1996). Concentrations of $\alpha-\mathrm{HCH}$ at Alert varied from $60-61 \mathrm{pg} / \mathrm{m}^{3}$ in $1993-94$ and decreased to $47 \mathrm{pg} / \mathrm{m}^{3}$ in 1997 , with an estimated time for $50 \%$ decrease of 10-16.9 y (Hung et al., 2002). A similar decline from the early to mid-1990s was recorded at a temperate site in Lista, Norway (Haugen et al., 1998).

The intercept $\left(83.4 \mathrm{pg} \mathrm{m}^{-3}\right)$ of Equation (1) can be interpreted as the background air concentration in the Arctic, which can be compared with the predicted $33-66$ pg $\mathrm{m}^{-3}$ air concentration of $\alpha-\mathrm{HCH}$ in equilibrium with Bering-Chukchi or eastern Arctic Ocean water in the 1990s. The linear relationship in Figure 3 indicates that the concentrations of $\alpha-\mathrm{HCH}$ in arctic air were dominated by primary emissions. Fugacity ratios within a factor of 2 of equilibrium values imply that today the arctic atmosphere is undergoing a transition to being buffered by secondary emissions from arctic waters, and perhaps also air-surface exchange with $\alpha-\mathrm{HCH}$ reservoirs in the temperate ocean and soils (Koziol and Pudykiewicz, 2001; Wania et al., 1999).

The concentrations and composition of $\alpha-\mathrm{HCH}$ in arctic air reflect this transition. On a transect from the Bering Sea across the polar cap to the Greenland Sea in 1994 , concentrations of $\alpha-\mathrm{HCH}$ in air were elevated over open water compared to ice-covered areas (Jantunen and Bidleman, 1996). Over unfrozen areas, nonracemic $\alpha-\mathrm{HCH}$ was found in air which reflected the enantiomer composition in surface water, while over ice-covered regions and land the $\alpha-\mathrm{HCH}$ in air was racemic due to predominently long-range transport contributions (Harner et al., 1999; Jantunen and Bidleman, 1996; Wiberg et al., 2001).

Even after global $\alpha-\mathrm{HCH}$ emissions approach zero, a background concentration of $\alpha-\mathrm{HCH}$ will remain in arctic air and decline slowly as levels in seawater dissipate. This is suggested by the slow decline of $\alpha-\mathrm{HCH}$ in arctic air, noted by Hung et al. (2002).

\section{Historical Air Concentration of $\alpha-\mathrm{HCH}$ in the Arctic}

Equation (1) is derived by using the data between 1979 and 1996. In order to calculate the air concentration of $\alpha-\mathrm{HCH}$ in the Arctic from global emissions before 1979 , this equation is not very accurate. By assuming the background value decreases linearly from 83.4 pg m-3 in 1979 to zero in 1945 when there was no any $\alpha-\mathrm{HCH}$ in arctic air since $\alpha-\mathrm{HCH}$ was not used in anywhere of the world, a modified equation is proposed for the calculation of air concentration of $\alpha-\mathrm{HCH}$ in the Arctic prior to 1980 :

$$
C=4.31 E+2.46(Y-1945)
$$

where $Y$ is the year between 1945 and 1978. The concentrations of $\alpha-\mathrm{HCH}$ in arctic air calculated from the annual global emissions using Equation (5) for 1945-78 and Equation (1) for 1979-96 are presented in Figure 4, and the measurement data in the arctic atmosphere are also presented for comparison. The calculated emissions fit the measurement data very well between 1979 and 1990, but deviate somewhat after 1990 where an almost constant air concentration of $\alpha-\mathrm{HCH}$ was appeared even though the global $\alpha-\mathrm{HCH}$ emissions kept decreasing.

\section{Conclusions}

The air concentrations of $\alpha-\mathrm{HCH}$ in the Arctic responded quickly to the change of global $\alpha-\mathrm{HCH}$ emissions from 1979 to the early 1990, since these two parameters were strongly correlated during this period of time.

The quick response and the strong correlation indicate that atmospheric long-range transport was the major pathway for $\alpha-\mathrm{HCH}$ to enter the Arctic before early 1990s, and has played a dominant role in air-water exchange. After early 1990s, the situation has changed substantially. The decrease of $\alpha-\mathrm{HCH}$ emissions brought the system to steady state and in some locations reversed the direction of the net flux of $\alpha-\mathrm{HCH}$ from air-to-sea to sea-to-air and the Arctic Ocean became a source of $\alpha-\mathrm{HCH}$. Since then, the air concentrations of $\alpha-\mathrm{HCH}$ in the Arctic have not responded to the change of global $\alpha-\mathrm{HCH}$ emissions anymore. Stable $\alpha-\mathrm{HCH}$ concentrations in arctic air are expected in the future since the $\alpha-\mathrm{HCH}$ concentration in air will be buffered by equilibration with arctic seawater, in which $\alpha-\mathrm{HCH}$ concentrations are decreasing slowly.

The correlation between air concentrations of $\alpha-\mathrm{HCH}$ in the Arctic and global $\alpha-\mathrm{HCH}$ emissions before the early 1990 was so strong that air concentrations of $\alpha-\mathrm{HCH}$ in the Arctic can be estimated from the data of global 
$\alpha-\mathrm{HCH}$ emissions with a high accuracy between 1979 to the early 1990s. Most importantly, this gives the estimation of air concentrations of $\alpha-\mathrm{HCH}$ in the Arctic before 1979 when the monitoring data are not available, which could be crucial for modelers to calculate the historical mass balance of $\alpha-\mathrm{HCH}$ in the Arctic Ocean.

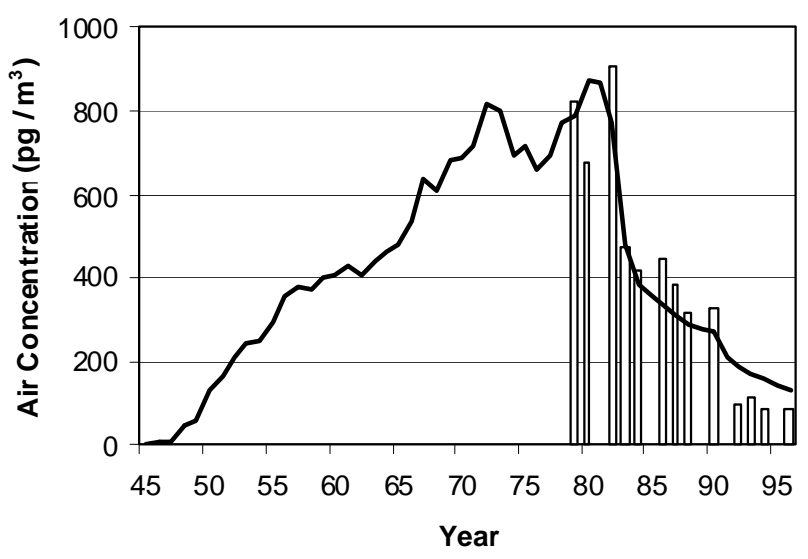

Note: Measurement data (bars) in the Arctic atmosphere are also presented for comparison.

Figure 4. The concentrations of $\alpha-\mathrm{HCH}$ in Arctic air calculated from the annual global emissions using Equation (1) for the years between 1980 and 1996 and Equation (5) for the years between 1945 and 1980 (curve).

Acknowledgments. Financial supports from the Canadian Northern Contaminants Program (NCP) are highly appreciated. The helpful comments from two anonymous reviewers are also gratefully acknowledged.

\section{References}

Barrie, L.A., Gregor, D., Hargrave, B., Lake, R., Muir, D., Shearer, R., Tracy, B. and Bidleman, T. (1992). Arctic contaminants: sources, occurrences and pathways. Sci. Total Environ., 122, 1-74.

Bidleman, T.F., Jantunen, L.M., Falconer, R.L., Barrie, L.A. and Fellin, P. (1995). Decline of hexachlorocyclohexane in the Arctic atmosphere and reversal of air-sea gas exchange. Geophys. Res. Lett., 22, 219-222.

Falconer, R.L., Bidleman, T.F. and Gregor, D.J. (1995). Air-water gas exchange and evidence for metabolism of hexachlorocyclohexanes in Resolute Bay. Sci. Total Environ., 160/161, 65-74.

Halsall, C.J., Bailey, R., Stern, G.A., Barrie, L.A., Fellin, P., Muir, D.C.G., Rosenberg, B., Rovinsky, Y.F., Kononov, E.Y. and Pastukhov, B. (1998). Multi-year observations of organohalogen pesticides in the Arctic atmosphere. Environ. Pollut., 102, 51-62.

Hargrave, B.T., Vass, W.P., Erickson, P.E. and Fowler, B.R. (1988). Atmospheric transport of organochlorines to the Arctic Ocean. Tellus, 40B, 480-493.

Harner, T., Kylin, H., Bidleman, T.F. and Strachan, W.M.J. (1999). Removal of $\alpha$ - and $\gamma$-hexachlorocyclohexane and enan- domers of $\alpha$-hexachlorocyclohexane in the eastern Arctic Ocean. Environ. Sci. Technol., 33, 1157-1164.

Haugen, J.-E., Wania, F., Ritter, N. and Schlabach, M. (1998). Hexachlorocyclohexanes in air in southern Norway: temporal variation, source allocation, and temperature dependence. Environ. Sci. Technol., 32, 217 -224.

Hinckley, D.A., Bidleman, T.F. and Rice, C.P. (1991). Atmospheric organochlorine pollutants and air-sea exchange of hexachlorocyclohexane in the Bering and Chukchi seas. J. Geophys. Res., 96C, 7201-7213.

Hung, H., Halsall, C.J., Blanchard, P., Li, H.H., Fellin, P., Stern, G. and Rosenberg, B. (2002). Temporal trends of organochlorine pesticides in the Canadian Arctic atmosphere. Environ. Sci. Technol., 36, 862-868.

IRPTC (1983). International register of potentially toxic chemicals, lindane, in N.F. Izmerov (Ed.), Scientific Reviews of Soviet Literature on Toxicity and Hazards of Chemicals, USSR Acad. of Medical Sci., Cent. of Int. Proj., GKNT, Moscow, No. 40, pp. 1-14.

Iwata, H., Tanabe, S., Sakai, N. and Tatsukawa, R. (1993). Distribution of persistent organochlorine pollutants in the oceanic air and surface seawater and the role of ocean on their global transport and fate. Environ. Sci. Technol., 27, 1080-1098.

Jantunen, L.M. and Bidleman, T.F. (1995). Reversal of the air-water gas exchange direction of hexachlorocyclohexanes in the Bering and Chukchi Seas: 1993 versus 1988. Environ. Sci. Technol., 29, 1081-1089.

Jantunen, L.M. and Bidleman, T.F. (1996). Air-water gas exchange of hexachlorocyclohexanes (HCHs) and the enantiomers of $\alpha-\mathrm{HCH}$ in Arctic regions. J. Geophys. Res., 101, 837-846.

Jantunen, L.M. and Bidleman, T.F. (2000). Temperature dependent Henry's law constant for technical toxaphene. Chemosphere, Global Change Science, 2, 225-231.

Koziol, A.S. and Pudykiewicz, J. (2001). Global-scale environmental transport of persistent organic pollutants, Chemosphere, 45, 1181-1200.

Kucklick, J.R., Hinckley, D.A. and Bidleman, T.F. (1991). Determination of Henry's law constants for hexachlorocyclohexanes in distilled water and artificial seawater as a function of temperature. Mar. Chem., 34, 197-209.

Kutz, F.W., Wood, P.H. and Bottimore, D.P. (1991). Organochlorine pesticides and polychlorinated biphenyls in human adipose tissue. Rev. Environ. Contam. Toxicol., 120, $1-82$.

Li, Y.F. (1999a). Global technical hexachlorocyclohexane usage and its contamination consequences in environment: From 1948 to 1997. Sci. Total Environ., 232, 123-160.

Li, Y.F. (1999b). Global gridded technical Hexachlorocyclohexane usage inventory by using a global cropland as a surrogate. J. Geophys. Res., 104-D19, 23785-23797.

Li, Y.F., Scholtz M.T. and van Heyst, B.J. (2000). Global gridded emission inventory of $\alpha-\mathrm{HCH} . J$. Geophys. Res., 105-D5, 6621-6632.

Li, Y.F., Bidleman, T.F., Barrie, L.A. and McConnell, L.L. (1998). Global hexachlorocyclohexane use trends and their impact on the Arctic atmospheric environment. Geophys. Res. Lett., 25, 39-41.

Li, Y.F., Macdonald, R.W., Jantunen, L.M.M., Harner, T., Bidleman, T.F. and Strachan, W.M.J. (2002). The transport of $\beta$-hexachlorocyclohexane to the western Arctic Ocean: a con-

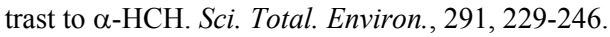

Macdonald, R.W., Barrie, L.A., Bidleman, T.F., Diamond, M.L., Gregor, D.J., Semkin, R.G., Strachan, W.M.J., Li, Y.F., Wania, 
F., Alaee, M., Backus, S., Bewers, M., Gobeil, C., Halsall, C., Hoff, J., Lockhart, L., Mackay, D., Muir, D., Pudykiewicz, J., Reimer, K., Smith, J., Stern, G., Schroeder, W., Wagemann, R. and Yunker, M. (2000). Contaminants in the Canadian Arctic: five years of progress in understanding sources, occurrence and pathways. Sci. Total. Environ., 254, 93-234.

Oehme, M. (1991). Dispersion and transport paths of toxic persistent organochlorines to the Arctic-levels and concequences. Sci. Total Environ., 106, 43-53.

Oehme, M. and Ottar, B. (1984). The long-range transport of polychlorinated hydrocarbons to the Arctic. Geophys. Res. Lett., 11, 1133-1136.

Oehme, M., Haugen, J.-E. and Schlabach, M. (1995). Ambient levels of persistent organochlorines in spring, 1992 at Spitzbergen and the Norwegian mainland, comparison with 1984 results and quality control measures. Sci. Total Environ., 160/161, 139-152.

Oehme, M., Schlabach, M., Kallenborn, R. and Haugen, J.E. (1996). Sources and pathways of persistent polychlorinated pollutants to remote areas of the North Atlantic and levels in the marine food chain: a research update. Sci. Total Environ., $186,13-24$

Pacyna, J.M. and Oehme, M. (1988). Long-range transport of some organic compounds to the Norwegian Arctic. Atmos. Environ., 22, 243-257.
Patton, G.W., Walla, M.D., Bidleman, T.F. and Barrie, L.A. (1991). Polycyclic aromatic and organochlorine compounds in the atmosphere of Northern Ellesmere Island, Canada. J. Geophys. Res., 96-D6, 10867-10877.

Patton, G.W., Hinckley, D.A., Bidleman, T.F. and Hargrave, B.T. (1989). Airborne organochlorine compounds in the Canadian High Arctic. Tellus, 41B, 243-255.

Sahsuvar, L., Helm, P.A., Jantunen, L.M. and Bidleman, T.F. (2002). Henry's law constants for $\alpha-, \quad \beta$ - and $\gamma$-hexachlorocyclohexanes (HCHs) as a function of temperature and re-assessment of gas exchange in arctic regions. Atmos. Environ. (under review).

Tanabe, S. and Tatsukawa, R. (1980). Chlorinated hydrocarbons in the North Pacific and Indian Oceans. J. Oceanographical Soc. Japan, 36, 217-226.

Wania, F., Mackay, D., Li, Y.F., Bidleman, T.F. and Strand, A. (1999). Global chemical fate of $\alpha$-hexachlorocyclohexane. 1. Evaluation of a global distribution model. Environ. Toxicol. Chem., 18, 1390-1399.

Wiberg, K., Brorström-Lundén, E., Wängberg, I., Bidleman, T.F. and Haglund, P. (2001). Concentrations and fluxes of hexachlorocyclohexanes (HCHs) and chiral composition of $\alpha-\mathrm{HCH}$ in environmental samples from the southern Baltic Sea. Environ. Sci. Technol., 36, 4739-4746. 